\title{
DEPURATION OF COPPER AND ZINC BY GREEN OYSTERS AND BLUE MUSSELS OF TAIWAN
}

\author{
Bor-Cheng Han \\ School of Public Health, Taipei Medical College, Taipei, Taiwan \\ Woei-Lih Jeng \\ Institute of Oceanography, National Taiwan University, Taipei, Taiwan \\ Ya-Ni Tsai \& Ming-Shiou Jeng \\ Institute of Zoology, Academia Sinica, Taipei, Taiwan
}

(Received 23 March 1992; accepted 10 August 1992)

\begin{abstract}
This paper describes depuration processes of copper and zinc in green oysters (Crassostrea gigas) and in blue mussels (Mytilus smarangdium) collected from an environment with heavy copper contamination, and then transferred to natural clean seawater. Results show that the total loss of copper content per oyster is an exponential function of exposure time for the first 6 days with a depuration rate of $351 \mathrm{\mu g} \mathrm{g}^{-1}$ day $^{-1}$ and then levels off. During this exponential decrease period approximately $67 \%$ of the copper accumulated in green oysters was depurated. However, when the copper contents in the oysters decreased from $2225 \pm 111 \mu \mathrm{g} \mathrm{g}^{-1}$ to $344 \pm$ $18.7 \mu \mathrm{g} \mathrm{g}^{-1}$ the depuration rates decreased from $245 \mu \mathrm{g}$ $\mathrm{g}^{-1}$ day ${ }^{\prime}$ to $0.08 \mu \mathrm{g}^{\prime}$ day ${ }^{-1}$. This means that green oysters had a 16-fold higher copper depuration rate (351 $\mu \mathrm{g} \mathrm{g}^{-1}$ day $\left.{ }^{-1}\right)$ than normal oysters $\left(21.5 \mu g \mathrm{~g}^{-1}\right.$ day $\left.{ }^{-1}\right)$ for the first 6 days. However, the depuration of accumulated copper and zinc by the mussels was a fast process in natural clean seawater. About $91 \%$ of the accumulated copper was lost during the first 6-day period; copper contents declined from $20 \cdot 2 \pm 3.41 \mu \mathrm{g} \mathrm{g}^{-1}$ to $1 \cdot 80 \pm 0 \cdot 21 \mu \mathrm{g}$ $\mathrm{g}^{-1}$. Only $36 \%$ of the accumulated zinc was lost during a depuration period of 6 days. Calculations show that the biological half-lives of copper in green and normal oysters were 11.6 and 25.1 days, respectively. The biological half-lives of zinc in green and normal oysters were 16.7 and 30.1 days, respectively. In spite of the relatively low initial copper content in blue mussels being $20 \cdot 2 \pm$ $3.41 \mu \mathrm{g} \mathrm{g}^{-1}$, the biological half-life is only 6.40 days. From these results it is important to emphasise that the fastest turnover rate is for copper in blue mussels. However, zinc is more retentive in blue mussels than copper.
\end{abstract}

Environ. Pollut. 0269-7491/93/\$06.00 (C) 1993 Elsevier Science Publishers Ltd, England. Printed in Great Britain

\section{INTRODUCTION}

Heavy metal pollution is the most serious and one of the most studied marine environmental problems in Taiwan because the water and sediment of most major harbours are heavily polluted. South-western Taiwan is especially affected because of the large discharge of heavy metals from land sources to the sea. The major source of heavy metals comes from acid cleaning of metal scrap on the river banks. For example, the first case of green oysters (Crassostrea gigas) occurred along the Charting mariculture area of south-western Taiwan in January 1986 (Su et al., 1986). The green colour in oysters was found to be due to high copper content in the oyster tissue (Han \& Hung, 1990). Hundreds of millions of dollars were lost because a major sector of aquaculture in this region had to be closed down. As a result all seafood industry suffered from the green oyster incident. Different measures are underway now to ameliorate the problem (Chu et al., 1988).

Han and Hung (1990) reported that the highest copper content of $4401 \pm 79 \mu \mathrm{g} \mathrm{g}{ }^{1}$ (dry wt) in green oysters was obtained from the Erhjin Chi estuary. The relatively high concentrations of particulate and total dissolved copper were generally found in samples from the Erhjin Chi estuary station compared with those from the coast of Charting (Hung \& Han, 1992). Meanwhile, an experiment of copper accumulation in oysters was conducted in the Erhjin Chi estuary and at Charting for up to 90 days. On the other hand, the concentrations of copper and zinc, and accumulation rates in the oysters following various periods of exposure time from two culture locations have been given elsewhere (Han \& Hung, 1989, 1990). For instance, bioaccumulation in the field experiment shows that the total uptake of copper per oyster is an exponential function of exposure time for the first 2 weeks with an 
accumulation rate of $214 \mu \mathrm{gg}{ }^{\prime}$ day ' and then levels off (Fig. 2, Han and Hung, 1990).

The ability of bivalves to eliminate heavy metals, such as $\mathrm{Zn}, \mathrm{Cd}, \mathrm{Pb}$ and $\mathrm{Cu}$, is well known. In any event, release of soluble and particulate materials is the prime mechanism by which marine organisms redistribute pollutants in their environment (Fowler, 1982). However, the contributions of these mechanisms to the total heavy metal content in bivalves are still uncertain. Generally, heavy metals in or on oysters are eliminated in either soluble or particulate form. However, there is little information on the loss of metals from oysters in Taiwan. Especially, it is interesting to show how fast the depuration rate is from green oysters under natural clean seawater conditions. Therefore, the purpose of this work was to describe depuration processes of metals in green oysters and blue mussels (Mytilus smarangdium). Meanwhile, this paper also calculates biological halflives in order to quantify depuration processes.

\section{MATERIALS AND METHODS}

To study the bioaccumulation of trace metals by the oysters, cultures of approximately 5000-6000 individuals (age 1 month) were suspended at two stations in the Erhjin Chi estuary (S1) and Charting coastal area (S2) for a period of 3 months (Fig. 1). The oysters at S1 turned their colour into green with a copper content of $2225 \mu \mathrm{g} \mathrm{g}^{-1}$ and those at S2 did not show any change

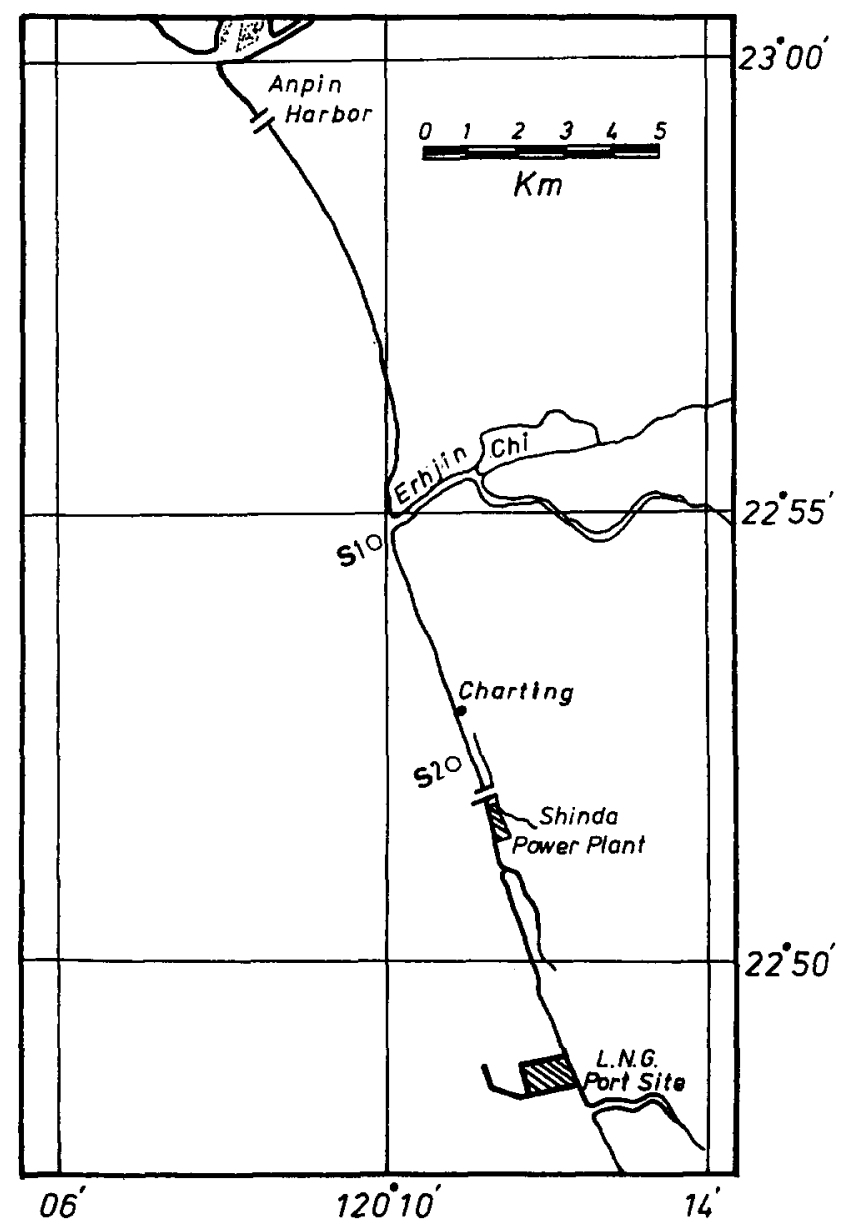

Fig. 1. Oyster culture and sampling stations along the Erhjin Chi estuary and Charting coastal area. in colour visually with a copper content of $606 \mu \mathrm{g} \mathrm{g}^{-1}$ and were therefore assumed to be normal. However, the depuration experiments were carried out in the laboratory for a 32-day exposure in natural clean seawater. The bivalves were not fed during the experiment. Individual green oysters and blue mussels of similar size were sampled on day 0 to obtain initial dry weights and heavy metal concentration in tissues. At each time interval during depuration, average concentrations of heavy metals in few parts of tissue were obtained from the results of the three bivalves analyses.

The culture medium (clean seawater) was collected from off the eastern coast (uncontaminated environment) of Taiwan, containing total copper and zinc concentrations of less than 1.0 and $3.0 \mu \mathrm{g}$ litre $^{-1}$, respectively. The seawater was changed every other day, well aerated and maintained at room temperature with a salinity of $30 \%$ and a $\mathrm{pH}$ range of $7 \cdot 8-8 \cdot 2$.

After a time period of depuration green oysters and blue mussels were collected and digested with a $1: 1$ mixture of nitric and sulphuric acid (v/v) solution (AOAC, 1975), and the supernatant analysed for heavy metals by atomic absorption spectrophotometry (Hitach Z-8000). NBS oyster tissue standard (NBS 1566, USA) was also used as control (Han \& Hung, 1990). The concentrations of copper and zinc in seawater samples were analysed by differential pulse anodic stripping voltammetry (EG \& G Model 384B Polarographic Analyzer) (Chen et al., 1989).

The biological half-lives of copper and zinc in green oysters and blue mussels were calculated by employing the method developed by Renfro (1973).

\section{RESULTS AND DISCUSSION}

\section{Mechanisms of depuration copper and zinc in bivalves}

The concentrations of copper and zinc and depuration rates in the oysters and blue mussels following various time periods of exposure are given in Table 1, and the data illustrated in Figs 2 and 3. It is worth noting that depuration of copper and zinc by green oysters and mussels appeared to decrease exponentially with time during the first 32-day period. For instance, for green oysters collected from the Erhjin Chi estuary station (S1), the total loss of copper per oyster is an exponential function of exposure time for the first 6 days with a depuration rate of $351 \mu \mathrm{g} \mathrm{g}^{-1}$ day $^{-1}$ and then levels off (Fig. 2). During this period approximately $67 \%$ of the copper accumulated in green oysters was depurated. After a 16-day incubation, the colour of green oysters returned to normal, and the depuration rate dropped to $33.4 \mu \mathrm{g} \mathrm{g}^{-1}$ day $^{-1}$. However, when the copper contents in the oyster decreased from $2225 \pm 111 \mu \mathrm{g} \mathrm{g}^{-1}$ to $344 \pm 18.7 \mu \mathrm{g} \mathrm{g}^{-1}$, the depuration rates decreased from $245 \mu \mathrm{g} \mathrm{g}^{-1} \mathrm{day}^{-1}$ to $0.08 \mu \mathrm{g} \mathrm{g}^{-1} \mathrm{day}^{-1}$ (Table 1). In other words, the depuration rates generally decrease until a steady state is reached between the copper in the incubation water and the oyster tissue, i.e. no apparent change of concentration in oysters with time.

On the other hand, it was also found that the 
Table 1. Depuration of metals by oysters (Crassostrea gigas) and mussels (Mytilus smarangdium) following a 32-day exposure in natural seawater ${ }^{a}$

\begin{tabular}{|c|c|c|c|c|c|c|c|c|}
\hline \multirow[t]{2}{*}{ Station } & \multirow[t]{2}{*}{ Organism } & \multirow{2}{*}{$\begin{array}{c}\text { Exposure } \\
\text { time } \\
\text { (days) }\end{array}$} & \multirow{2}{*}{\multicolumn{2}{|c|}{$\begin{array}{c}\text { Copper } \\
\left(\mu \mathrm{g} \mathrm{g}^{-1}\right)\end{array}$}} & \multirow{2}{*}{\multicolumn{2}{|c|}{$\begin{array}{c}\text { Zinc } \\
\left(\mu \mathrm{g} \mathrm{g}^{-1}\right)\end{array}$}} & \multicolumn{2}{|c|}{ Depuration rate } \\
\hline & & & & & & & Copper & Zinc \\
\hline \multirow[t]{8}{*}{ S1 } & Oysters & 0 & 2225 & (111) & 1001 & $(50 \cdot 8)$ & & \\
\hline & & 2 & 1736 & $(85.2)$ & $\begin{array}{l}705 \\
567\end{array}$ & $(46.9)$ & $\begin{array}{l}-245 \\
-143\end{array}$ & $\begin{array}{l}-148 \\
-68.9\end{array}$ \\
\hline & & $\begin{array}{l}4 \\
6\end{array}$ & $\begin{array}{r}1449 \\
746\end{array}$ & $(75 \cdot 4)$ & $\begin{array}{l}567 \\
304\end{array}$ & $(50 \cdot 1)$ & $\begin{array}{l}-143 \\
-351\end{array}$ & $\begin{array}{l}-68.9 \\
-86.8\end{array}$ \\
\hline & & $\begin{array}{r}6 \\
10\end{array}$ & $\begin{array}{l}746 \\
668\end{array}$ & $(45 \cdot 0)$ & 394 & $(44 \cdot 3)$ & -351 & $\begin{array}{r}-86 \cdot 8 \\
18.2\end{array}$ \\
\hline & & 10 & 668 & $(49 \cdot 2)$ & 321 & $(18.4)$ & $-19 \cdot 7$ & $-18 \cdot 2$ \\
\hline & & 16 & 467 & $(50 \cdot 3)$ & 272 & $(25 \cdot 7)$ & $-33 \cdot 4$ & $-8 \cdot 11$ \\
\hline & & 23 & 345 & $(29.2)$ & 243 & $(32 \cdot 8)$ & $-17 \cdot 5$ & $-4 \cdot 11$ \\
\hline & & 32 & 344 & $(18.7)$ & 242 & $(40 \cdot 2)$ & -0.08 & $-0 \cdot 14$ \\
\hline \multirow[t]{8}{*}{$\mathbf{S} 2$} & Oysters & 0 & 606 & $(52 \cdot 7)$ & 458 & $(37 \cdot 6)$ & & \\
\hline & & 2 & 478 & $(65 \cdot 1)$ & 350 & $(25 \cdot 8)$ & -63.9 & -53.9 \\
\hline & & 4 & 447 & $(40 \cdot 2)$ & 181 & $(30 \cdot 2)$ & $-15 \cdot 3$ & -84.9 \\
\hline & & 6 & 404 & $(40.8)$ & 184 & $(25 \cdot 7)$ & $-21 \cdot 5$ & 1.89 \\
\hline & & 10 & 306 & $(29.8)$ & 175 & $(20 \cdot 8)$ & $-24 \cdot 6$ & $-2 \cdot 31$ \\
\hline & & 16 & 263 & $(32.7)$ & 170 & $(31 \cdot 2)$ & $-7 \cdot 18$ & $-0 \cdot 81$ \\
\hline & & 23 & 248 & $(30 \cdot 1)$ & 173 & $(10-8)$ & -2.08 & $0 \cdot 32$ \\
\hline & & 32 & 249 & $(28.4)$ & 169 & $(9.20)$ & -0.01 & -0.42 \\
\hline \multirow[t]{6}{*}{ S2 } & Mussels & 0 & $20 \cdot 2$ & $(3.41)$ & 103 & $(9.21)$ & & \\
\hline & & 2 & $5 \cdot 10$ & $(2 \cdot 14)$ & 82 & $(10 \cdot 8)$ & $-7 \cdot 53$ & $-10 \cdot 5$ \\
\hline & & 4 & $2 \cdot 4$ & $(1.84)$ & 84 & $(7.51)$ & $-1 \cdot 33$ & 0.91 \\
\hline & & 6 & 1.80 & $(0.21)$ & 66 & $3(7.55)$ & -0.33 & $-8 \cdot 84$ \\
\hline & & 10 & 1.9 & $(0 \cdot 18)$ & 64 & $2(10 \cdot 3)$ & -0.03 & -0.53 \\
\hline & & 17 & 1.8 & $(0.23)$ & 62 & $4(8.42)$ & -0.02 & -0.26 \\
\hline
\end{tabular}

${ }^{a}$ All data are the mean of three determinations. The numbers in parentheses are the standard deviations.

depuration pattern of zinc is similar to that of copper by green oysters (Fig. 3). For example, a low final zinc concentration of $242 \pm 40 \cdot 2 \mu \mathrm{g} \mathrm{g}^{-1}$ was observed with a 32-day incubation (Table 1). In general, the depuration rate of copper is higher than that of zinc by green oysters. Perhaps this is due to the oysters having a high initial copper content of $2225 \pm 111 \mu \mathrm{g} \mathrm{g}^{-1}$.

The depuration rates of copper and zinc of green oysters from the Erhjin Chi estuary ( $\mathrm{Sl}$ ) and those of normal oysters from the Charting coastal area (S2) are also presented in Table 1 . The results reveal that the green oysters had higher copper and zinc depuration rates than normal oysters for the first 6 days. For example, the green oysters had a 16-fold higher copper depuration rate $\left(351 \mu \mathrm{g} \mathrm{g}^{-1}\right.$ day $\left.{ }^{1}\right)$ than normal oysters (21.5 $\mu \mathrm{g} \mathrm{g}^{-1}$ day $\left.^{-1}\right)$. However, during this period only $33.3 \%$ of the copper accumulated was depurated from normal oysters (Table 1). These results suggest that the depuration rates of copper and zinc were influenced by the initial total metal content in the oysters, but the depuration rates were not directly proportional to the body burden because the initial depuration rates were significantly faster than later depuration rates (Riisgard et al., 1987). One may be concerned about the possible effect of desorption from shells. This effect is negligible at the $\mathrm{pH}$ of natural seawater since heavy metal desorption from solid substrates (e.g. shells) is generally possible under the acidic environment.

From our results it is found that for oysters and blue mussels growing at the same location (S2), i.e. under the same physico-chemical conditions, oysters are more effective at bioaccumulating for copper and zinc (Table 1). The ratios of metal concentration in oysters to that in mussels are 30 for copper and 4 for zinc (Table 1). The results explained that mussels can regulate copper and zinc (Bryan et al., 1985). In other words, the copper concentration is higher in the oysters than in the mussels, which is obviously related to the fact that copper plays a different role in the oyster metabolism than in that of the mussel (Martincic et al., 1984). The present study has confirmed that oysters have a great capacity for accumulating copper and zinc, and concentrations as high as $2000-4000 \mu \mathrm{g} \mathrm{g}^{-1}$ dry weight apparently do not have harmful effects. This capacity makes oysters a good candidate for monitoring copper and zinc in the marine environment.

In addition, the depuration of accumulated copper and zinc by the mussels was a fast process in natural clean seawater. About $91 \%$ of the accumulated copper was lost during the first 6-day period; copper content declined from $20.2 \pm 3.41$ to $1.80 \pm 0.21 \mu \mathrm{g} \mathrm{g}^{-1}$ (Table 1). It can be seen that the depuration was rapid within the first 6 days, and then levelled off (Fig. 2). So, the rate of release of copper was faster in the mussel. However, the rate of depuration of zinc was slow (Fig. 3). Only $36 \%$ of the accumulated zinc was lost during a depuration period of 6 days. The zinc content reached a value of $62.4 \pm 8.42 \mu \mathrm{g} \mathrm{g}^{-1}$ from $103 \pm 9.21 \mu \mathrm{g} \mathrm{g}^{-1}$ during the experiment period. During this time period approximately $40 \%$ of the zinc body burden was depurated (Table 1). The slow rate of zinc released in blue mussels indicates the possibility of forming strong metal complexes within the tissue components (Lakshmanan \& Nambisan, 1989). It might be that a certain fraction of zinc may have been immobilised by metallothioneins (Martincic et al., 1984). 


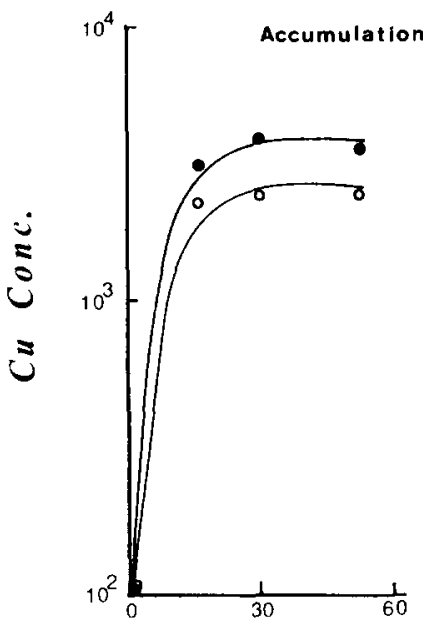

EXPOSURE

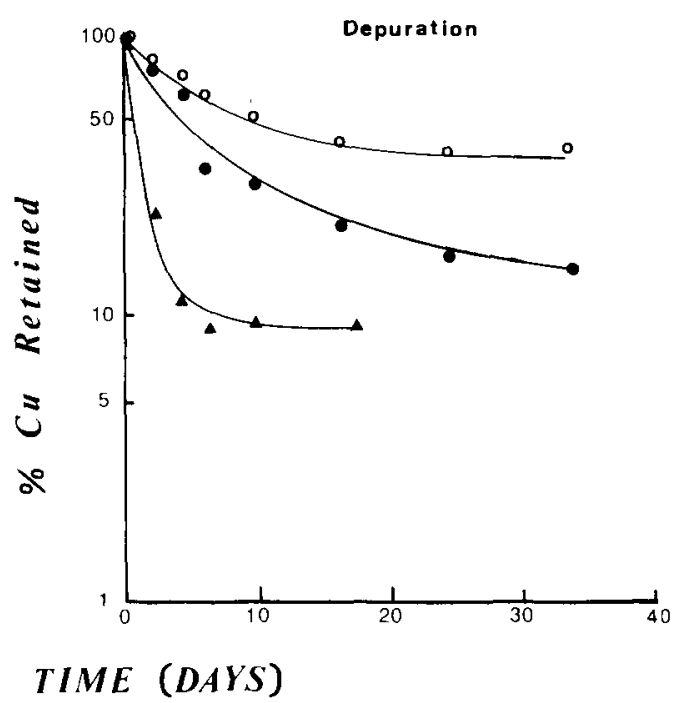

Fig. 2. Accumulation (Han \& Hung, 1990) and depuration of copper ( $\mu \mathrm{g} \mathrm{g}^{-1}$, dry wt) in oysters $(\mathbf{O}, \mathbf{S 1}$; $\mathrm{O}, \mathbf{S 2})$ and mussels (A, S2) collected from two culture stations.

On the whole, the accumulation and depuration patterns have been shown by plotting the total copper and zinc content per organism as a function of time (Figs 2 and 3). The non-linear depuration of copper and zinc may indicate an increasing depuration rate when the total body burden of copper and zinc is increased. Generally, when bivalves are transferred from a contaminated to a clean environment, there is an initial rapid drop in trace metal concentration followed by a slower loss. The initial rapid loss can be due to desorption of loosely bound metals, a depuration of unassimilated materials, release of non-metabolised compounds, etc., whereas the slower depuration rates generally reflect loss from pools within the bivalve where the contaminant is more tightly bound to tissue components (Fowler, 1982).

\section{Biological half-lives for copper and zinc in bivalves}

Biological half-life (the time for one-half of the pollutant to be lost from an organism or a pool within the organisms) is a useful tool to quantify the elimination process (Fowler, 1982). Measurement of biological half-life is usually done in the laboratory using radiotracers; however, accumulation and depuration experiments in this study were conducted in the field and in natural clean seawater, respectively. Biological half-lives were therefore estimated using these data. Estimates of the biological half-life $\left(B_{1 / 2}\right)$ for each metal in bivalves showing a progressive loss during depuration were obtained by the method of Renfro (1973). Here, the equation $\log y=a+b x$ was fitted to the depuration data where $y$ is the percentage of the initial tissue concentration observed at 0 depuration time, $b$ is the slope of the line, $x$ is the depuration period starting with 0 days, and $a$ is the intercept on the $y$ axis. Then, the slope $(b)$ of the least-squares regression line was substituted in the equation (Denton \& Burdon-Jones, 1981):

$$
B_{1 / 2}(\text { days })=(\log 2) / b
$$

The $B_{1 / 2}$ values for copper and zinc in green oysters and blue mussels showing a progressive loss during depura-
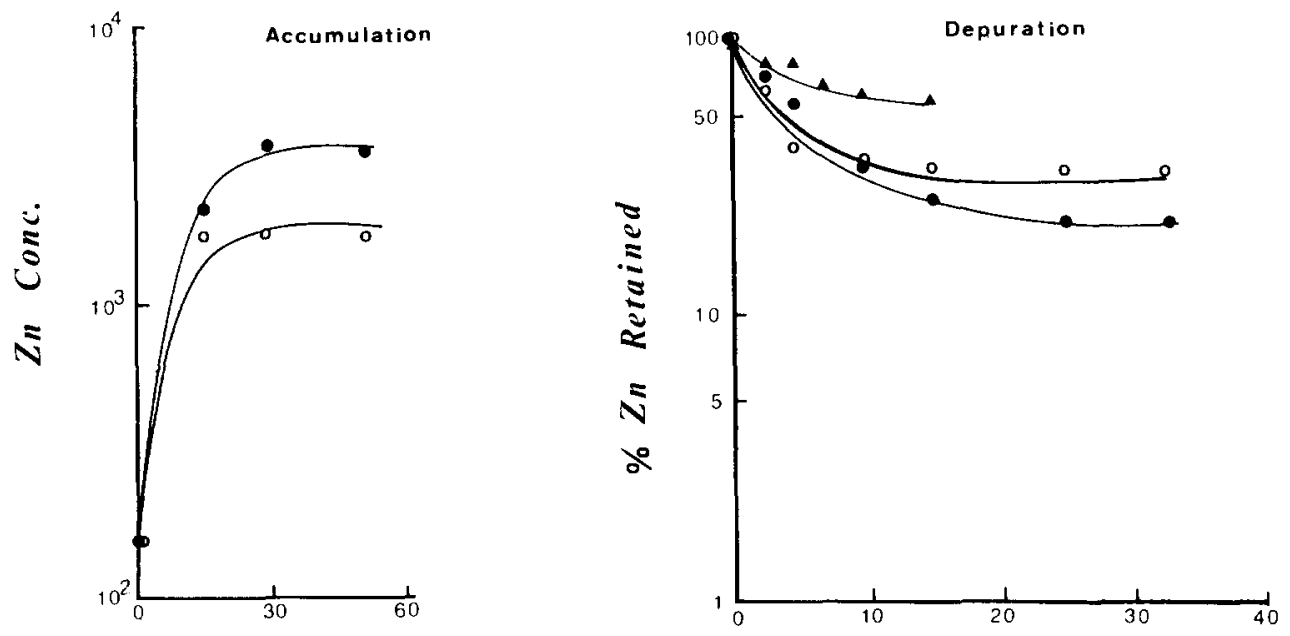

EXPOSURE TIME (DAYS)

Fig. 3. Accumulation (Han \& Hung, 1990) and depuration of zinc $\left(\mu \mathrm{g} \mathrm{g}^{-1}\right.$, dry wt) in oysters $(\boldsymbol{O}, \mathbf{S 1} ; \bigcirc, \mathbf{S} 2)$ and mussels $(\boldsymbol{\Lambda}, \mathbf{S} 2)$ collected from two culture stations. 
Table 2. Biological half-lives ( $B_{1 / 2}$, days) for depuration of copper and zinc from oysters (Crassostrea gigas) and mussels (Mytilus smarangdium)

\begin{tabular}{llcccc}
\hline Station & Organism & Metal & $\begin{array}{c}\text { Equation } \\
(\log y=a-b x)\end{array}$ & $\begin{array}{c}\text { Correlation } \\
\text { coefficient }\end{array}$ & $\begin{array}{c}B_{1 / 2} \text { (days) } \\
(\log 2) / b\end{array}$ \\
\hline S1 & Oysters & $\mathrm{Cu}$ & $\log y=1.850-\mathbf{0 . 0 2 6 x}$ & $\mathbf{0 . 9 0 9 ^ { a }}$ & $11 \cdot 6$ \\
S2 & Oysters & & $\log y=1.906-0.012 x$ & $0.888^{a}$ & $25 \cdot 1$ \\
S2 & Mussels & & $\log y=1.536-0.047 x$ & $0.705^{a}$ & 6.40 \\
S1 & Oysters & $\mathrm{Zn}$ & $\log y=1.818-0.018 x$ & $0.859^{a}$ & 16.7 \\
S2 & Oysters & & $\log y=1.783-0.010 x$ & $0 \cdot 632^{a}$ & $30 \cdot 1$ \\
S2 & Mussels & & $\log y=1.942-0.012 x$ & $0.848^{a}$ & $25 \cdot 1$ \\
\hline
\end{tabular}

a Significant at $P<0.05$.

tion (i.e. negative slope) are shown in Table 2. From the table it is seen that the $B_{1 / 2}$ values of copper in green and normal oysters were 11.6 and 25.1 days, respectively (Table 2). This suggested that the depuration rate of copper by normal oysters was two times slower than that by green oysters. It also implies that the depuration rates in oysters decrease with decreased initial copper content. In other words, in green oysters copper loss was characterised by a decrease in the $B_{1 / 2}$ value with an increase in the body burden of copper (Pringle et al., 1968).

On the other hand, Table 2 also shows the biological half-lives for zinc in green and normal oysters. It is found that the biological half-life of zinc is similar to the results of copper in oysters. The biological halflives of zinc in green and normal oysters were 16.7 and $30 \cdot 1$ days, respectively.

Bivalves typically retain metals for a long time; biological half-lives of roughly 1 year or more have been reported for some elements (Fowler, 1982). However, for oysters and blue mussels, biological half-lives range from days to weeks depending upon the element, organisms and the way in which it is accumulated. For example, despite initial copper contents in blue mussels being $20.2 \pm 3.41 \mu \mathrm{g} \mathrm{g}^{-1}$, the biological half-life is only 6.40 days. From these results it is important to emphasise the highest turnover rate in blue mussels. Furthermore, these results reveal that zinc stays longer in blue mussels than copper due to different ability in regulating copper and zinc. Rarely is the loss rate constant over the entire period of depuration; thus both fast and slow components with different half-lives are normally observed (Fowler, 1982).

However, some metals do not behave in this manner; for example, lead and cadmium are lost from green oysters at rates which are independent of metal contents. There was steady-state accumulation and release of lead and cadmium by the green oysters throughout the experiment. An emerging trend from our related studies shows that metals in oysters tend to be lost in the order copper $>$ zinc $>$ lead $>$ cadmium.

\section{ACKNOWLEDGMENTS}

The authors would like to thank Professor T. C. Hung and $\mathrm{Mr} \mathrm{C}$. H. Tsai of the Institute of Oceanography, National Taiwan University for financial support of the study and collection of marine organisms, respectively.

\section{REFERENCES}

AOAC (1975). Methods of Analysis, ed. W. Horwitz. Association of Official Analytical Chemists, Washington, DC, USA, pp. 453-5.

Bryan, G. W., Langston, W. J., Hummerstone, L. G. \& Burt, G. R. (1985). A guide of the assessment of heavy-metal contamination in estuaries using biological indicators. Mar. Biol. Ass. UK, Plymouth, Devon, UK, Occasional Publication No. 4.

Chen, K. S., Han, B. C. \& Hung, T. C. (1989). Organic copper in the coastal water of Taiwan. Bull. Inst. Chem., Academia Sinica, 36, 105-13.

Chu, C. M. K., Chen, C. T. A., Shieh, C. S. \& Duedall, I. W. (1988). Marine science education and research in Taiwan, ROC. Sea Technol., 29, 45-52.

Denton, G. R. W. \& Burden-Jones, C. (1981). Influence of temperature and salinity on the uptake, distribution and depuration of mercury, cadmium and lead by the black-lip oyster Saccostrea echinata. Mar. Biol., 64, 317-26.

Fowler, S. W. (1982). Biological transfer and transport processes. In Pollutant Transfer and Transport in the Sea, ed. G. Kullenberg. CRC Press, Boca Raton, FL, USA, pp. 1-65.

Han, B. C. \& Hung, T. C. (1989). Kinetics of heavy metal accumulation in oysters from Charting mariculture area of Taiwan. J. Chinese Environ. Prot. Soc., 12(2), 92117.

Han, B. C. \& Hung, T. C. (1990). Green oysters caused by copper pollution on the Taiwan coast. Environ. Pollut., 65, $347-62$.

Hung, T. C. \& Han, B. C. (1992). Relationships among the species of copper, organic compounds and bioaccumulation along the mariculture area in Taiwan. Sci. Total Environ., 125, 359-72.

Lakshmanan, P. T. \& Nambisan, P. N. K. (1989). Bioaccumulation and depuration of some trace metals in the mussel, Perna viridis (Linnaeus). Bull. Environ. Contamin. Toxicol., 43, 131-8.

Martincic, D., Nurnberg, H. W., Stoeppler, M. \& Branica, M. (1984). Bioaccumulation of heavy metals by bivalves from Lim Fjord (North Adriatic Sea). Mar. Biol., 81, 177-88.

Pringle, B. H., Hissong, D. E., Katz, E. L. \& Mulawka, S. T. (1968). Trace metal accumulation by estuarine molluscs. J. Sanit. Engng Div. Am. Soc. Civ. Engrs, 94, 455-75.

Renfro, W. C. (1973). Transfer of ${ }^{65} \mathrm{Zn}$ from sediments by marine polychaete worms. Mar. Biol., 21, 305-16.

Riisgard, H. U., Bjornestand, E. \& Mohlenberg, F. (1987). Accumulation of cadmium in the mussel Mytilus edulis: kinetics and importance of uptake via food and sea water. Mar. Biol., 96, 349-53.

Su, J. C., Hung, T. C. \& Chen, J. C. (1986). Ecological and Environmental Studies Along the Erhjin Chi (River) Estuary and Coastal Area. SCOPE/ROC, Academia Sinica Special Publication No. 43. 